\title{
PERTIMBANGAN HAKIM DALAM MEMUTUSKAN PERKARA DISPENSASI NIKAH BERDASARKAN ANALISIS MASLAHAH (Studi Penetapan Hakim No. 266/Pdt.P/2020/PA.Pwr di Pengadilan Agama Purworejo)
}

\section{Waluyo Sudarmaji}

Sekolah Tinggi Agama Islam An-Nawawi Purworejo, Indonesia

\begin{abstract}
In the event that the prospective bride and groom will hold a marriage registered at the local Office of Religious Affairs If the age is less than 19 years, it will be rejected because the marriage conditions are not fulfilled. Because the marriage is considered urgent to be carried out, then parents or guardians can apply for a marriage dispensation at the Religious Court. Marriage dispensation is an application for ratification of a marriage that will take place by the prospective bride and groom or one of the prospective brides who are not old enough to marry. This research is the result of research on the consideration of judges in deciding the case of marital dispensation with the analysis of maslahah with the main problem of consideration of judges in deciding the case and the analysis of maslahah. This research is analitive descriptive qualitative research with normative approach, data source used by primary data source in the form of interviews, observations, and secondary data in the form of court determination. The technical analysis of data used is qualitative approach to primary data and secondary data. The purpose of this research is what the judge considered in the Purworejo Religious Court in granting the application for marital dispensation on the determination No. 266/Pdt.P/2020/PA/Pwr, and to find out the determination of judges in the Purworejo Religious Court regarding marital dispensation which is analyzed through maslahah. Based on the results of the research conducted, it can be concluded that the consideration of the judge in granting the request for marital dispensation is on the grounds that the marriage is urgent to be done, between the husband and wife there is no obstacle to marriage and the two families have approved each other. In the analysis maslahah consideration of judges included in the maslahah doruriyah because to maintain religion and descendants.
\end{abstract}

Keywords: consideration of judges, dispensation of marriage, maslahah

\section{INTRODUCTION}

Dalam Undang-Undang pasal 7 ayat (1) No 1 Tahun 1974 dinyatakan bahwa pernikahan hanya boleh dilakukan jika pihak pria sudah mencapai usia 19 tahun dan pihak perempuan 16 tahun. Kemudian pada bulan Oktober 2019 terjadi perubahan yaitu tertuang dalam Undang-Undang N0. 16 Tahun 2019 tentang perubahan batas usia pernikahan yaitu pernikahan hanya dapat dilakukan apabila pihak pria telah mencapai usia 19 tahun dan usia pihak perempuan usia 19 tahun, jadi perubahannya ada pada usia minimal pihak perempuan yang dulu 16 tahun menjadi 19 tahun. ${ }^{1}$ Apabila kedua mempelai belum mencukupi batas usia pernikahan maka pemerintah telah mengatur

${ }^{1}$ Undang-Undang No. 16 Tahun 2019. 
dalam pasal 7 ayat (2), di mana dalam pasal tersebut dijelaskan bahwa dalam hal terjadi penyimpangan terhadap ketentuan umur yang telah diatur, maka orang tua dapat meminta permohonan dispensasi nikah yang dapat diajukan kepada Pengadilan Agama. ${ }^{2}$ Dispensasi nikah yang disebutkan di atas merupakan permohonan pengesahan pernikahan yang dilangsungkan, yang para calon mempelai atau salah satu dari calon mempelai belum mencukupi umur untuk menikah.

Permohonan dispensasi nikah dapat diajukan kepada Pengadilan Agama dan harus diajukan oleh wali dari pihak yang ingin mendapatkan dispensasi nikah. Permohonan dispensasi nikah yang diajukan oleh pihak pemohon berkaitan erat dengan Pengadilan yang memiliki hak untuk menolak atau mengabulkan dispensasi nikah yang telah diajukan apabila alasan-alasan yang dikemukakan tidak dapat menjadi faktor pendukung yang kuat. Maka dari itu, kehati-hatian dan kebijaksanaan dari pihak Pengadilan memiliki peran yang sangat penting dalam menerima permohonan dispensasi nikah yang memiliki alasan yang kuat, sehingga jumlah permohonan dispensasi nikah dapat ditekan.

Dalam praktiknya di Pengadilan Agama, majelis Hakim mempunyai alasanalasan tersendiri dalam memutusan perkara yang masuk. Baik itu ada alasan internal maupun eksternal. Diantara alasan Majlis Hakim dalam memutuskan perkara dispensasi nikah yaitu melihat bahwa pernikahan tersebut mendesak untuk segera dilakukan karena kedua belah pihak telah menjalin hubungan erat selama 2 tahun, sehingga apabila dibiarkan dan tidak segera dinikahkan ditakutkan akan terjadi hal yang tiak diinginkan. Selain itu, juga melihat bahwa dari kedua belah pihak sudah siap untuk menjalani rumah tangga. Alasan tersebut dijadikan sebuah patokan demi terpenuhinya unsur maslahah yang sejatinya harus dipenuhi dalam setiap penetapan dispensasi nikah dan harus memenuhi seperti yang diinginkan syariat. Maka dari itu peneliti tertarik untuk meneliti pertimbangan Hakim dalam memutuskan perkara dispensasi nikah yang kemudian dianalisis dengan maslahah.

\section{DISCUSSION (Book Antiqua 11,5pt, Bold, Justify, Uppercase) Pernikahan}

Pernikahan dalam literatur fiqih bahasa berbahasa arab disebut dengan dua kata yaitu nikah dan zawaj. Kedua kata ini biasa digunakan dalam kehidupan sehari-hari. ${ }^{3}$ Secara bahasa pernikahan diungkapan dengan ungkapan makna mengumpulkan, hubungan biologis (wathi'), dan akad. Secara syara' yaitu akad yang memuat rukun dan syarat. ${ }^{4}$

Dalam hukum Islam dijelaskan pernikahan merupakan suatu akad antara calon mempelai pria dan calon mempelai wanita atas dasar kerelaan dan suka diantara kedua

${ }^{2}$ Pasal 7 Ayat (2) Undang- Undang No. 16 Tahun 2019. hlm. 35 .

${ }^{3}$ Amir Syarifudin, Hukum Perkawinan Islam Di Indonesia, (Jakarta: Kencana, 2016),

${ }^{4}$ M. Hamim. HR, Terjemah Fathul Qorib, (Kediri: Santri Salaf Press, 2017), hlm. 393. 
belah pihak yang diakadkan oleh seorang wali dengan jelas berupa ijab qobul yang dilaksanakan dihadapan kedua orang saksi dengan memenuhi syarat. ${ }^{5}$ Sementara dalam Kompilasi Hukum Islam dijelaskan bahwa pernikahan adalah suatu akad yang kuat yang diucapkan oleh wali dan qobul yang diucapkan oleh mempelai laki-laki dan disaksikan oleh kedua orang saksi. Pernikahan dilakukan untuk menaati perintah Allah dan melaksanakannya merupakan ibadah. Tujuannya yaitu untuk untuk membentuk keluarga yang sakinah mawaddah warohmah. ${ }^{6}$

Dijelaskan pula dalam Undang-Undang No. 1 Tahun 1974 pernikahan merupakan sebuah ikatan lahir batin antara seorang laki-laki dan seorang perempuan sebagai suami istri dengan tujuan membentuk keluarga yang bahagia dan kekal berdasarkan ketuhanan Yang Maha Esa. ${ }^{7}$

1. Batas Usia Pernikahan

Pembatasan usia pernikahan di Indonesia diatur dalam Undang-Undang No. 16 Tahun 2019 yang merupakan perubahan pasal 7 Undang-Undang No. 1 Tahun 1974. Dalam Undang-Undang No. 16 Tahun 2019 disebutkan bahwa pernikahan hanya diizinkan bagi calon mempelai yang sudah berusia 19 tahun, baik pihak laki-laki mauupun pihak perempuan. ${ }^{8}$ Dalam Kompilasi Hukum Islam juga telah dijelaskan bahwa pembatasan usia minimal pernikahan yaitu terdapat dalam pasal 15 ayat (1) yang menyebutkan bahwa pernikahan boleh dilakukan oleh calon mempelai yang telah mencapai batas usia pernikahan yang disebutkan dalam Undang-Undang. ${ }^{9}$ Apabila dari kedua belah pihak atau salah satu dari pihak yang akan melaksanakan pernikahan belum memenuhi batas minimal usia pernikahan, maka dapat diajukan permohonan dispensasi nikah untuk mendapatkan izin menikah.

Batas usia minimal pernikahan menurut para ulama tidak menentukan secara khusus batas usia pernikahnnya, namun membatasi bahwa usia minimal pernikahan termasuk dalam syarat sah menikah yaitu baligh. Nur Ihdatul Musyarrafa dalam jurnalnya mengutip pendapat dari Imam Syafi'i mengemukakan bahwa Imam Syafi'i tidak melarang pada usia berapa seseorang dapat melangsungkan pernikahan. Namun Imam Syafi'i juga menganjurkan bahwa idealnya seseorang melangusngkan pernikahan yaitu ketika seseorang sudah baligh. ${ }^{10}$

Adapun untuk usia baligh para ulama sepakat bahwa menstruasi dan hamil merupakan sebuah bukti seseorang telah masuk pada usia baligh. Kedudukan menstruasi sama dengan mimpi basah bagi seorang laki-laki. Imam

${ }^{5}$ Hilman Hadikusuma, Hukum Perkawinan, (Bandung: Mandar Maju, 2007), hlm. 10.

${ }^{6}$ Abdurrahman, Kompilasi Hukum Islam, Hlm. 1

${ }^{7}$ Undang-Undang No. 1 Tahun 1974

${ }^{8}$ Undang-undang no. 16 tahun 2019

${ }^{9}$ Team Citra Umbara, Kompilasi Hukum Islam, hlm. 327-328.

10 Nur Ihdatul Musyarrafa, Batas Usia Pernikahan Dalam Islam, Jurnal Shautuna, Vol. 1, No. 3, September 2020, hlm. 715 . 
Syafi'i dan Imam Hambali berpendapat bahwa baligh bagi laki-laki dan perempuan yaitu lima belas tahun. Sementara itu Imam Maliki berpendapat bahwa usia baligh bagi laki-laki dan perempuan tujuh belas tahun. Sedangkan Imam Hanafi menetapkan usia baligh bagi laki-laki delapan belas tahun dan bagi perempuan tujuh belas tahun. ${ }^{11}$

2. Dispensasi Nikah

Dalam Kamus Besar Bahasa Indonesia dispensasi memiliki arti pengecualian dari sebuah aturan karena adanya pertimbangan yang khusus, pembebasan dari suatu kewajiban atau larangan. ${ }^{12}$ Dispensasi nikah adalah pemberian hak kepada seseorang untuk melaksanakan pernikahan meski usia dari kedua mempelai atau salah satu mempelai belum mencapai batas usia pernikahan. ${ }^{13}$ Di Indonesia pemberian dispensasi nikah harus melalui proses sidang dengan cara mengajukan permohonan dispensasi nikah ke Pengadilan Agama.

Pada Undang-Undang No. 16 Tahun 2019 tentang perubahan atas pasal 7 ayat (1) tahun 1974 tentang Perkawinan dinyatakan bahwa pernikahan boleh dilakukan apabila mempelai pria dan mempelai wanita telah berusia 19 tahun. $^{14}$

Permohonan dispensasi nikah dapat diajukan ke Pengadilan Agama bagi calon mempelai yang beragama Islam dan ke Pengadilan Negeri bagi calon mempelai yang bukan beragama Islam. Permohonan dispensasi nikah hraus dilengkapi dengan surat pengantar dari kepala desa atau kelurahan setempat dengan ketetuan telah memenuhi syarat.

Adapun syarat administrasi untuk mengajukan dispensasi nikah ke Pengadilan Agama yang tercantum dalam Peraturan No. 5 Tahun 2019 sebagai berikut:

a. Surat permohonan

b. Fotocopy kartu tanda penduduk kedua orang tua/wali

c. Fotocopy kartu keluarga

d. Fotocopy kartu tanda penduduk atau kartu identitas anak atau akta kelahiran anak

e. Fotocopy kartu tanda penduduk atau kartu identitas anak atau akta kelahiran calon suami atau istri

f. Fotocopy ijazah pendidikan terakhir anak atau surat keterangan masih sekolah dari sekolah anak. ${ }^{15}$

Namun dalam praktiknya di Pengadilan Agama, bahwasanya sebuah penetapan dispensasi nikah akan digunakan apabila sudah ada surat penolakan

${ }^{11}$ Muhammad Jawad Mughniyah, Fiqih Lima Madzhab, (Jakarta: Lentera, 2004), hlm. 317-318.

12 Departemen Pendidikan Nasional, Kamus Besar Bahasa Indonesia, (Jakarta: Gramedia Pustaka Utama, 2011), hlm. 335.

${ }^{13}$ Safrin Salam, Dispensasi Pernikahan Anak Di Bawah Umur Dalam Persfektif Hukum Adat, Hukum Negara Dan Hukum Islam, Jurnal Pagaruyuang, Vol. 1 No. 1, Juni 2017, hlm 114.

${ }^{14}$ Undang-Undang No 16 Tahun 2019

15 Ibid. 
dari Kantor Urusan Agama (KUA) yang telah menolak pendaftaran nikah dari seseorang karena calon mempelai belum mencapai batas usia pernikahan. Maka syarat untuk mengajukan permohonan harus ada surat penolakan terlebih dahulu dari KUA tempat calon mempelai mendaftarkan pernikahan. Sehingga nantinya penetapan dispensasi nikah yang keluar dari Pengadilan Agama akan digunakan untuk mendapat ijin menikah di KUA. Karena KUA akan menikahkan seseorang yang belum mencapai batas mininal usia pernikahan jika sudah mendapat izin untuk menikah dengan menunjukkan penetapan dari Pengadilan Agama. Adapun syarat adminstrasi untuk mengajukan permohonan dispensasi nikah di Pengadilan yaitu:
a. Surat permohonan
b. Fotocopy kartu tanda penduduk Pemohon atau kedua Orang Tua/Wali
c. Fotocopy buku nikah Pemohon
d. Surat penolakan dari KUA
e. Fotocopy kartu keluarga
f. Fotocopy ijazah pendidikan terakhir anak atau surat keterangan masih sekolah dari sekolah anak.
g. Membayar biaya perkara.

Jika salah satu dari syarat yang telah disebutkan di atas tidak terpenuhi maka, permohonan tersebut ditolak oleh Pengadilan. ${ }^{16}$

\section{Mașlahah}

Dari segi bahasa, mașlahah berasal dari kata salaha yang arti katanya yaitu baik. Kata tersebut merupakan masdar dari șaluha yaitu kebaikan atau terlepas dari kesusahan. Maṣlaḩah juga bentuk tunggal dari kata yang berarti sesuatu yang mendatangkan kebaikan. ${ }^{17}$ Secara etimologi mașlaḥah sama saja dengan manfaat baik, baik itu dari segi lafad maupun makna atu suatu pekerjaan yang mengandung kebaikan atau kemanfaatan. Dalam Kamus Besar Bahasa Indonesia dijelaskan bahwa arti mașlahah yaitu sesuatu yang mendatangkan kebaikan, faedah dan guna. ${ }^{18}$ Secara terminologi mașlahah memiliki beberapa definisi yang dikemukakan oleh para ulama ushul fiqih, namun dari definisi yang dikemukakan oleh ulama ushul fiqih tersebut memiliki makna yang sama.

Pada prinsipnya, mașlahah merupakan suatu yang nisbi karena banyak maslahah yang di dalamnya juga terkandung unsur mafsadat, namun banyak juga mafsadat yang mengandung unsur mașlahah, seperti pada khamr atau minuman keras. Akan tetapi diambil dari segi yang paling kuat dan banyak. Para ulama Fiqh memberikan batas pada mașlahah yang dapat diterima dan disimpulkan dalam

\footnotetext{
${ }^{16}$ Data dari Dokumen di Pengadilan Agama Purworejo

17 A. Warson Munawir, Kamus Al-Munawir, (Surabaya: Pustaka Progresif, 1997), hlm. 788-789.

${ }^{18}$ Departemen Pendidikan Nasional, Kamus Besar Bahasa Indonesia, hlm. 884.
} 
kaidah fiqhiyyah. Dengan begitu dapat disimpulkan bahwa mașlahah merupakan suatu hal yang mendatangkan manfaat dan menjauhkan dari madharat. ${ }^{19}$

Adapun tujuan syara' yang harus dipelihara ada 5 macam yaitu menjaga agama, menjaga jiwa, menjaga akal, menjaga keturunan, dan menjaga harta. Apabila seseorang melakukan perbuatan yang tujuannya untuk mencapai kelima tujuan syara' tersebut maka itu disebut sebagai maslahah, dan segala upaya untuk menolak kemudharatan yang masih berkaitan dengan kelima aspek tersebut juga disebut mașlahah. ${ }^{20}$

Adapun macam-macam Mașlahah yaitu sebagai berikut:

a. Dilihat dari segi segi kualitas dan kepentingan, mașlahah dibagi menjadi 3 yaitu:

1) Mașlahah Daruriyyah

Mașlahah daruriyyah merupakan kemaslahatan yang berhubungan dengan kebutuhan pokok manusia baik di dunia maupun di akhirat, yaitu memelihara agama, menjaga jiwa, menjaga akal, menjaga keturunan, dan menjaga harta. ${ }^{21}$ Kelima unsur ini juga disyariatkan oleh Allah Swt dalam firmannya surah al-Mumtahanah ayat 12:

Artinya: "Hai Nabi, apabila datang kepadamu perempuan-perempuan yang beriman untuk Mengadakan janji setia, bahwa mereka tiada akan menyekutukan Allah, tidak akan mencuri, tidak akan berzina, tidak akan membunuh anak-anaknya, tidak akan berbuat Dusta yang mereka ada-adakan antara tangan dan kaki mereka dan tidak akan mendurhakaimu dalam urusan yang baik, Maka terimalah janji setia mereka dan mohonkanlah ampunan kepada Allah untuk mereka. Sesungguhnya Allah Maha Pengampun lagi Maha Penyayang." (Q.S Al-Mumtahanah : 12)22

Mașlahah daruriyyah merupakan maslahah yang menjadi dasar tegaknya kehidupan hak asasi manusia, baik itu berkaitan dengan dunia maupun dengan akhirat. Seperti yang telah disebutkan oleh Zakaria Bisri bahwasanya mașlahah daruriyah merupakan hak asasi bagi kelangsungan hidup, jika ia rusak maka akan timbul fitnah dan bencara besar. ${ }^{23}$

Memeluk suatu agama adalah fitrah bagi setiap manusia, dan tidak bisa dipungkiri bahwa itu adalah kebutuhan manusia. Untuk itu Allah mensyariatkan Agama yang wajib untuk dipelihara oleh setiap manusia, baik itu berkaitan dengan akidah, ibadah maupun muamalah. Hak untuk hidup di dunia juga merupakan hak asasi bagi manusia. Kaitannya dengan mașlahah yaitu termasuk dalam menjaga jiwa. Sebagaimana Allah telah mensyariatkan bermacam-macam hukum yang ada kaitannya dengan

\footnotetext{
${ }^{19}$ Mardi Candra, Aspek Perlindungan Anak Indonesia, (Jakarta: Kencana, 2018), hlm. 41.

${ }^{20}$ Ibid., hlm. 115

${ }^{21}$ Jurnal Justitia, Mașlahah Dan Perkembangannya Sebagai Dasar Penetaan Hukum Islam, Jurnal Justitia, Vol. 1 No 04 Desember 2014, hlm. 354

${ }^{22}$ Departemen Agama, Al-Qur'an dan Terjemahnya, hlm. 551

${ }^{23}$ Satria Efendi, Ushul Fiqih, (Jakarta: Prenada Media, 2005). hlm 120.
} 
menjaga jiwa, seperti kesempatan untuk menggunakan hasil alam untuk mempertahankan hidup manusia. ${ }^{24}$

Akal juga berfungsi untuk manusia menjaga hidup dan kehidupannya. Maka dari itu Allah menjadikan memelihara akal menjadi salah satu hal yang pokok. Akal akan hilang saat seseorang dalam keadaan tidak sadar, maka dari itu Allah melarang manusia untuk minum minuman keras karena hal tersebut dapat membuat akal menjadi hilang atau rusak. Jika akal manusia telah rusak maka akan rusak pula kehidupan manusia. Selanjutnya yaitu berketurunan, berketurunan juga termasuk dalam masalah pokok dalam kehidupan manusia. Untuk meneruskan kehidupan di bumi maka manusia harus mempunyai keturunan. Untuk memelihara dan melanjutkan keturunan maka Allah telah mensyariatkan pernikahan dan segala hak dan kewajiban yang timbul akibat pernikahan, pernikahan dilakukan dengan tujuan salah satunya yaitu mempunyai keturunan. Keturunan yang sah hanya dapat diperoleh dari sepasang laki-laki dan perempuan yang telah menikah. Yang terakhir manusia tidak bisa hidup tanpa harta, karena harta juga termasuk salah satu yang pokok dalam kehidupan manusia. Maka dari itu Allah juga mensyariatkan untuk memelihara hartanya, seperti contohnya untuk menghukum perampok yang telah mengambil barang seseorang. ${ }^{25}$

2) Mașlahah Hajiyyah

Merupakan mașlahah yang tingkat kebutuhan hidup manusia padanya tidak sampai pada tingkat daruri. ${ }^{26}$ Bentuk kemaslahatannya tidak langsung pada pemenuhan kebutuhan pokok yang lima. Mașlahah hajiyyah dibutuhkan untuk melestarikan kelima pokok dasar dalam rangka perwujudan dan perlindungan. Apabila mașlahah hajiyyah tidak terlaksana maka tidak akan merusak eksistensi lima pokok dasar, hanya saja akan menyebabkan kesempitan atau kesulitan, baik dalam usaha mewujudkan maupun pelaksaannya. Dalam agama Islam kesempitan dan kesulitan itu seharusnya disingkirkan.27

3) Mașlahah At-Tahsiniyyah

Kebutuhan at-Tahsiniyyah merupakan kebutuhan yang apabila tidak terpenuh maka tidak mengancam eksistensi pokok yang lima serta tidak menimbulkan kesulitan. Mașlaḥah At-Tahsiniyyah berada pada tingkatan pelengkap. Seperti yang dikemukakan oleh Asy-Syatibi seperti hal-hal yang

\footnotetext{
${ }^{24}$ Nasrun Haroen, Ushul Fiqh, hlm 115.

${ }^{25}$ Mukasana pasaribu, MaṢlahah Dan Perkembangannya Sebagai Dasar Penetaan Hukum Islam, hlm. 354.

${ }^{26}$ Saifudin Zuhri, Ushul Fiqih, (Yogyakarta: Pustaka Pelajar, 2011), hlm. 106.

${ }^{27}$ Nilda Susilawati, Statifikasi Al-Maqasid Al-Khamsah Dan Penerapannya Dalam Ad-Dharuriyat, AlHajiyyat, At-Tahsiniyyat, MIZANI, Vol. IX, No. 1, Februari 2015, hlm. 8.
} 
berhubungan dengan adat istiadat dan berhias dengan keindahan yang sesuai pada norma akhlak. ${ }^{28}$

Pada dasarnya, baik mașlahah daruriyyah, hajiyyah, dan tahsiniyyah yaitu untuk memelihara dan mewujudkan kelima pokok dasar yang telah disebutkan di atas, hanya saja berbeda tingkatan tergantung pada kepentingannya masing-masing. Pada mașlahah daruriyyah apabila kelima pokok dasar tersebut tidak terpenuhi maka akan terancam eksistensinya, karena daruriyyah termasuk dalam ketegori kebutuhan yang primer. Kemudian pada mașlahah hajiyyah berada pada tingkatan sekunder, yang bilamana kelima pokok dasar tersebut tidak terpenuhi tidak akan mengancam eksistensinya, namun akan mempersempit kehidupan manusia. Dan pada mașlahah tahsiniyyah merupakan tingkatan yang berkaitan erat dengan upaya untuk menjaga etika dan tidak akan mempersempit maupun mempersulit juga tidak akan mengancam eksistensinya, maṣlahah tahsiniyyah bisa dikatakan sebagai pelengkap..$^{29}$

Melihat syarat-syarat untuk melaksanakan pernikahan menurut ketentuan hukum Islam dan ketentuan perundang-undangan telah terpenuhi kecuali satu persyaratan yaitu calon mempelai perempuan belum cukup usia untuk melaksanakan pernikahan berdasarkan pada peraturan perundang-undangan No. 16 Tahun 2019 yang menyebutkan bahwa pernikahan hanya boleh dilakukan apabila calon mempelai baik laki-laki maupun perempuan telah mencapai 19 tahun. Dalam kasus ini calon mempelai perempuan masih berusia 17 tahun sehingga belum mencapai batas usia minimal pernikahan, sehingga maksud dari pemohon untuk menikahkan putrinya ditolak oleh Kantor Urusan Agama dan harus mengajukan dispensasi nikah di Pengadilan Agama. ${ }^{30}$

Menurut Hakim Pengadilan Agama Purworejo bapak Junaedi., SHI. memandang Pernikahan tersebut mendesak untuk tetap dilaksanakan karena anak Pemohon dengan calon suaminya sudah menjalani hubungan selama 2 tahun dan telah melakukan lamaran pada tangga 13 Maret 2020 serta hubungan dari kedua belah pihak telah sedemikian erat sehingga ditakutkan akan melakukan perbuatan yang dilarang oleh agama serta norma susila apabila tidak segera dinikahkan. ${ }^{31}$

Menurut Pemohon, Antara anak Pemohon dan calon suaminya tidak terdapat hubungan darah, persusuan, dan tidak ada larangan yang menyebabkan pernikahan tidak dapat dilakukan. Anak Para Pemohon masih berstatus perawan atau belum pernah menikah, telah akil baligh dan sudah siap untuk menjadi seorang istri dan seorang ibu rumah tangga, begitupula calon suaminya juga seorang yang berstatus

\footnotetext{
${ }^{28}$ Satria Effendi, Ushul Fiqh, (Jakarta: Kencana, 2009), hlm. 236.

${ }^{29}$ Suyatno, Dasar-Dasar Ushul Fiqh Dan Ushul Fiqh, Cet 1, (Yogyakarta: Ar-Ruzz Media, 2011), hlm. 164.

${ }^{30}$ Penetapan No. 266/Pdt.P/2020/PA.Pwr, hlm. 3.

31 Wawancara dengan bapak Junaedi., S.H.I selaku Hakim di Pengadilan Agama Purworejo pada tanggal 07 oktober 2020
} 
perjaka atau belum pernah menikah serta telah siap untuk menjadi seorang suami atau seorang kepala rumah tangga. ${ }^{32}$

Keluarga Para Pemohon orang tua calon suami telah merestui hubungan keduanya dan merestui rencana pernikahan tersebut. Dan tidak ada pihak ketiga yang keberatan atas berlangsungnya pernikahan tersebut. Meskipun anak Para Pemohon masih dibawah usia pernikahan, namun secara lahir dan batin telah siap melaksanakan pernikahan serta Para Pemohon siap untuk membimbing dan menasehati anaknya. Dengan alasan demikian maka Para Pemohon mengajukan Permohonan Dispensasi Nikah untuk dan atas nama anak Para Pemohon kepada calon suaminya. ${ }^{33}$

1. Pertimbangan Hakim

Maksud dan tujuan permohonan Pemohon adalah sebagaimana disebutkan di atas, untuk itu selama proses persidangan Hakim telah berusaha menasehati Pemohon agar menunda pernikahan anak Pemohon hingga anak Pemohon mencapai batas usia yang ditentukan oleh Undang-Undang, namun usaha tersebut tidak berhasil hingga penetapan ini dijatuhkan. Dikarenakan perkara ini merupakan permohonan (voluntair), maka mediasi tidak perlu dilaksanakan, sebagimana diatur dalam buku II halaman 85 dan PERMA No. 2 tahun 2016. ${ }^{34}$

Dari hasil wawancara yang dilakukan oleh peneliti terhadap Para Pemohon, Pemohon menyebutkan bahwa Permohonan Para Pemohon pada pokoknya mendalilkan bahwa Para Pemohon memohon dispensasi nikah untuk anak kandung Para Pemohon dengan calon suaminya dikarenakan keduanya telah menjalin hubungan sejak 2 tahun yang lalu sampai sekarang serta untuk mengantisipasi kesulitan-kesulitan administratif yang mungkin timbul dikemudian hari apabila tidak segera dinikahkan. ${ }^{35}$ Baik Orang tua calon suami maupun Para Pemohon menyatakan sebagai orang tua mereka tidak memaksakan anaknya untuk menikah, namun itu datang dari keinginan anak sendiri. Mereka menginginkan pernikahan untuk segera dilaksanakan karena hubungan dari kedua belah pihak yang sudah begitu dekat. Para Pemohon dan orang tua calon suami juga akan bertanggung jawab baik dari segi materiil maupun immateriil bila anak Para Pemohon dan calon suaminya kelak berumah tangga. Para pemohon dan orang tua dari calon suami juga siap membimbing dan memberikan nasehat kepada anaknya apabila terjadi suatu masalah di kemudian hari. ${ }^{36}$

Kemudian Peneliti melakukan wawancara dengan anak para pemohon dan calon suaminya terkait hubungan dari keduanya. Anak Para Pemohon dan calon suaminya menyatakan bahwa pernikahan tersebut merupakan keinginan dari

\footnotetext{
${ }^{32}$ Wawancara dengan Pemohon di Pengadilan Agama Purworejo pada tanggal 18 September 2020

${ }^{33}$ Wawancara dengan Saksi dari keluarga Pemohon di Pengadilan Agama Purworejo pada tanggal 18 September 2020

${ }^{34}$ Hasil observasi di Pengadilan Agama Purworejo pada tanggal 18 September 2020.

${ }^{35}$ Wawancara dengan Pemohon di Pengadilan Agama Purworejo tanggal 18 September 2020

36 Wawancara dengan Para Pemohon dan orang tua calon suami di Pengadilan Agama Purworejo pada tanggal 18 September 2020.
} 
kedua belah pihak karena saling mencintai dan bukan paksaan dari siapapun termasuk orang tua dari calon mempelai wanita dan calon mempelai laki-laki serta menyatakan bahwa keduanya sudah menjalin hubungan selama 2 tahun. Para calon mempelai juga menyatakan bahwa ingin segera dalam ikatan yang sah, agar dapat menghindarkan dari segala hal yang dikhawatirkan akan terjadi. Anak Para pemohon juga menyatakan siap membangun dan menjalankan rumah tangga dikarenakan keduanya telah mengenal lama dan sudah memahami satu sama lain baik kekurangan maupun kelebihannya. ${ }^{37}$

Dari hasil observasi yang dilakukan oleh peneliti pada tanggal 18 September 2020 di Pengadilan Agama Purworejo bahwa dalam persidangan telah dihadirkan anak Para Pemohon, calon suami anak Pemohon, orang tua calon suami anak Para Pemohon, dengan demikian secara formal telah memenuhi ketentuan pasal 10 dan pasal 13 Peraturan Mahkamah Agung (PERMA) No. 5 tahun 2019 tentang Pedoman Mengadili Permohonan Dispensasi Kawin.

Dalam persidangan, Hakim juga telah memberikan nasehat kepada anak Para Pemohon, calon suami anak Para Pemohon, orang tua calon suami anak Para Pemohon tentang resiko perkawinan anak yang terkait dengan pendidikan anak, kesehatan reproduksi anak Para Pemohon, masalah ekonomi, sosial, dan kejiwaan anak serta berbagai problematika dalam rumah tangga dengan adanya potensi perselisihan dan kekerasan dalam rumah tangga (KDRT), namun semua pihak tetap dengan pendiriannya untuk melaksanakan perkawinan antara anak Pemohon dengan calon suaminya. ${ }^{38}$

Menurut Hakim di Pengadilan Agama Purworejo, melihat peraturan yang berlaku di Indonesia bahwa untuk melangsungkan pernikahan dan untuk mencapai tujuannya sebagaimana termuat dalam Pasal 1 Undang-Undang No 2 tahun 1974 tentang Perkawinan yang telah diubah dengan Undang-Undang No 16 Tahun 2019. Pasal 3 Kompilasi Hukum Islam yaitu membentuk keluarga yang sakinah mawaddah warahmah dan kekal berdasarkan Ketuhanan Yang Maha Esa perlu kesiapan fisik, mental, dan spiritual terutama bagi seorang perempuan yang akan menjadi calon istri dan calon ibu.

Maka negara mengatur batas usia minimal pernikahan sebagaimana termuat dalam pasal 7 ayat (1) Undang-Undang No. 16 tahun 2019 tentang perubahan Undang-Undang No 2 tahun 1974 tentang perkawinan yaitu calon mempelai wanita harus sekurang-kurangnya berusia 19 tahun. Dalam pasal 7 ayat (2) Undang-Undang No 16 tahun 2019 telah mengatur dalam hal penyimpangan batas usia pernikahan untuk melangsungkan pernikahan yaitu dengan mengajukan permohonan dispensasi nikah oleh orang tua calon mempelai kepada Pengadilan. Ketentuan tentang dispensasi atau keringanan usia pernikahan dinilai

\footnotetext{
${ }^{37}$ Wawancara dengan Anak Para Pemohon dan calon suaminya di Pengadilan Agama Purworejo pada tanggal 18 September 2020

${ }^{38}$ Hasil observasi di Pengadilan Agama Purworejo pada tanggal 18 September 2020
} 
Hakim sebagai sebuah pengecualian dari ketentuan umum dengan tanpa menggeser atau menghilangkan tujuan pernikahan sebagaimana yang telah dimaksud oleh peraturan perundang-undangan.

Tujuan pembatasan usia minimal pernikahan yaitu untuk menjaga kesehatan suami, istri dan keturunan. Hakim menilai bahwa kesehatan yang dimaksud merupakan kesehatan jasmani dan rohani sebagai modal mencapai tujuan pernikahan, sedangkan kesehatan keturunan yang dimaksud adalah bagian dari akibat adanya pernikahan. Kehendak yang memang datang dari kedua mempelai tanpa adanya paksaan dari orang lain, termasuk orang tua dari kedua orang tuanya masing-masing, menujukkan bahwa calon mempelai laki-laki dan calon mempelai perempuan dinilai telah memiliki kematangan berpikir yang matang atau rohani dimana itu merupakan kehendaknya sendiri tanpa adanya pengaruh, bujukan atau tekanan dari orang lain. Sehingga calon mempelai lakilaki dan calon mempelai wanita sadar akan akibat atau konsekuensi dari sebuah pernikahan. Usia pernikahan calon mempelai wanita belum genap 19 tahun sehingga tidak memenuhi syarat minimal usia perkawinan bagi calon istri. Kendati demikian bahwa permohonan dispensasi umur pernikahan bisa didasarkan kepada keadaan mendesak disertai bukti-bukti yang mendukung. ${ }^{39}$

Melihat dari fakta hukum diatas bahwa calon mempelai wanita dan calon mempelai laki-laki sudah berhubungan dengan sangat erat selama 2 tahun dan khawatir terjadil hal yang dilarang oleh agama. Melihat kondisi tersebut bapak Junaedi, SHI selaku hakim pengadilan Agama Purworejo menilai bahwa keadaan tersebut adalah keadaan yang mendesak dan akan sulit apabila akan menunda pernikahan hingga calon mempelai wanita berusia 19 tahun karena masih harus menunggu sekitar 2 tahun lagi. Umur 19 tahun merupakan syarat hukum yang bersifat administratif demi tujuan kemaslahatan yakni terjaminnya kesiapan jasmani, rohani, dan spiritual calon istri. Sedangkan keadaan yang mendesak seperti yang telah disebutkan di atas merupakan kondisi darurat yang apabila dicegah akan membawa kerusakan seperti terjadi perzinaan antara calon suami dan calon istri. ${ }^{40}$ Menurut Hakim yang juga menangani perkara dispensasi nikah yaitu bapak H. M. Sururi, S.Ag juga menyatakan alasan yang sama dengan bapak Junaedi, SHI, beliau juga mengkhawatirkan apabila tidak memberikan izin dispensasi nikah akan membuat mereka melakukan hal yang tidak baik seperti nikah di bawah tangan, karena jika menikah di bawah tangan akan memperpanjang masalah nantinya. Pernikahan di bawah tangan juga akan merugikan pihak perempuan. ${ }^{41}$

Berdasarkan dari pertimbangan-pertimbangan Hakim tersebut, maka bapak Junaedi, S.H.I dan bapak H. M. Sururi selaku Hakim yang menangani

\footnotetext{
39 Penetapan Hakim No. 266/Pdt.P/2020/PA.Pwr, hlm. 11.

40 Wawancara dengan bapak Junaedi, S.H.I selaku Hakim di Pengadilan Agama Purworejo pada tanggal 07 Oktober 2020

${ }^{41}$ Wawancara dengan bapak H. M. Sururi, S.Ag selaku Hakim di Pengadilan Agama Purworejo
} 
perkara dispensasi nikah di Pengadilan Agama Purworejo menilai bahwa menolak kerusakan dalam kasus ini harus didahulukan dari pada menggapai kemaslahatan sebagaimana kaidah fiqhiyyah yang menjadi pegangan Hakim, beliau berpendapat bahwa kaidah tersebut dijadikan sebagai dasar dalam memutuskan perkara dispensasi nikah, kaidah tersebut:

\section{Artinya:"menolak kerusakan didahulukan daripada menarik kemaslahatan"}

Menolak kerusakan lainnya adalah untuk menghindari calon mempelai laki-laki dan calon mempelai wanita menikah dengan cara nikah bawah tangan atau kawin yang tidak tercatat di Kantor Urusan Agama apabila tidak mendapatkan ijin dipensasi nikah dari Pengadilan. Dengan adanya nikah bawah tangan akan semakin besar kerusakan hukum yang terjadi terutama bagi calon mempelai wanita dan juga anak-anak kelak yang akan dilahirkan dari pernikahan bawah tangan. ${ }^{42}$

Meskipun dalam kondisi mendesak, Hakim tetap memperhatikan halangan dan larangan pernikahan yang dalam faktanya tidak ditemukan diantara anak Para Pemohon dan calon suaminya. Begitu juga komitmen para orang tua untuk ikut bertanggung jawab terhadap calon mempelai perempuan ketika masuk dalam pernikahan. Juga telah dipastikan dengan mendengar keterangan di dalam ruang sidang. ${ }^{43}$

2. Penetapan Hakim

Mengingat segala peraturan perundang-undangan yang berlaku dan hukum syar'i dalam perkara ini maka Hakim mengadili :

a. Mengabulkan permohonan Para Pemohon

b. Memberikan dispensasi kepada Para Pemohon untuk menikahkan anaknya

c. Membebankan kepada Para Pemohon untuk membayar biaya perkara sejumlah Rp 131.000.- (seratus tiga puluh satu ribu rupiah)

Demikian ditetapkan dalam rapat permusyawaratn Hakim yang dilangsungkan para haru Jumat 18 September $2020 \mathrm{M}$ bertepatan dengan tanggal 30 Muharram 1442 H. Oleh Junaedi, S.HI. sebagai Hakim dan penetapan tersebut diucapakn pada sidang terbuka untuk umum pada hari Jumat 18 September 2020 M bertepatan dengan 30 Muharram $1442 \mathrm{H}$ oleh Hakim tersebut dengan didampingi oleh Fina Nuriana, S. HI. Sebagai Panitera Pengganti serta dihadiri oleh Pemohon. ${ }^{4}$

Dalam kasus yang diambil oleh peneliti, merupakan kasus permohonan dispensasi nikah yang mana mempelai wanita masih berusia 17 tahun 10 bulan

\footnotetext{
${ }^{42}$ Wawancara dengan bapak Junaedi, S.H.I dan bapak H. M. Sururi, S.Ag selaku Hakim di Pengadilan Agama Purworejo pada tanggal 07 Oktober 2020

${ }^{43}$ Observasi di Pengadilan Agama Purworejo tanggal 18 September 2020.

${ }^{44}$ Penetapan Hakim No. 266/Pdt.P/2020/PA.Pwr, hlm. 13-14.
} 
sehingga tidak bisa melangsungkan pernikahan, karena adanya aturan bahwa pernikahan hanya bisa dilakukan apabila mempelai wanita dan mempelai laki-laki telah berusia 19 tahun. Berdasarkan pada fakta hukum yang telah diajukan oleh Pemohon, Hakim menilai bahwa pernikahan tersebut mendesak untuk dilakukan, karena keduanya telah bertunangan dan telah dekat selama 2 tahun sehingga dikhawatirkan terjadi sesuatu yang tidak diinginkan jika tidak segera dinikahkan.

Untuk menyelesaikan perkara tersebut, Hakim mempertimbangan segala kemungkinan yang akan terjadi apabila tidak diberikan izin dispensasi nikah. Kemungkinan yang akan terjadi seperti nikah di bawah tangan akan berdampak lebih serius lagi untuk istri dan anak. Maka Hakim di Pengadilan Agama Purworejo mempertimbangkan untuk menolak atau mengabulkan permohonan tersebut.

Dalam analisis mașlahah pertimbangan Hakim ini termasuk dalam mașlahah ḍharuriyyah karena pertimbangan Hakim dalam memberikan izin dispensasi nikah untuk menjaga agama dan menjaga keturunan.

1. Menjaga agama, maksud dari menjaga agama yaitu Hakim Pengadilan Agama Purworejo berusaha menjaga agama dari para pihak agar tidak terus menerus melakukan dosa berkelanjutan yang sulit untuk dihindari. Karena jika mereka terus menerus berpacaran tanpa ikatan yang sah akan merusak agamanya.

2. Menjaga keturunan maksud dari menjaga keturunan yaitu ketika sepasang manusia sudah tidak bisa menjaga perbuatan yang dilarang oleh Allah, perbuatan yang dilarang oleh Allah tersebut yaitu zina dimana perbuatan tersebut bisa mengakibatkan mereka mempunyai anak yang tidak sah dalam pernikahan.

Maka dispensasi nikah dikabulkan agar mejaga kuturunan agar tetap berasal dari pernikahan yang sah. Jadi dispensasi nikah ini dikabulkan agar tidak terjadi hal demikian. Namun, jika tidak dikabulkan akan mengakibatkan hal-hal yang menyebabkan kerusakan.

Dispensasi nikah juga untuk menjaga keturunan yaitu menghindarkan dari pernikahan di bawah tangan, karena pernikahan di bawah tangan juga bertentangan dengan undang-undang dan menghilangkan hak istri di hadapan hukum negara. Karena sejatinya status orang yang menikah di bawah tangan hanya memiliki status sah menurut agama namun tidak tercatat sah dalam aturan negara. Nantinya hal ini juga akan berdampak pada anak yang lahir dari pasangan tersebut, karena anak tersebut hanya mendapat pengakuan dari negara tetapi hanya tertulis telah lahir dari seorang ibu dan tidak tercantum nama ayahnya. Selain itu jika suatu saat terjadi perselisihan yang itu akan merugikan istri, istri tidak dapat menuntut ke Pengadilan. Suami juga akan sewenang-wenang jika hendak meninggalkan istrinya, karena istrinya tidak dapat menuntut.

\section{CONCLUSION (Subhead 1: Book Antiqua, Size 11,5, Capitalize Each Word, Bold)}

Pertimbangan Hakim merupakan suatu hal yang penting dalam mewujudkan nilai dari suatu putusan Hakim yang mengandung kepastian hukum dan juga keadilan, di samping itu juga mengandung kemaslahatan dan manfaat bagi para pihak yang bersangkutan, sehingga pertimbangan Hakim harus disikapi dengan teliti dan baik. 
Pertimbangan Hakim yang digunakan untuk menghasilkan penetapan No. 266/Pdt.P/2020/PA.Pwr yaitu mempertimbangkan apa yang menjadi alasan Pemohon mengajukan dispensasi nikah.

Adapun dasar hukum yang digunakan oleh Hakim dalam memutuskan perkara dispensasi nikah No. 266/Pdt.P/2020/PA.Pwr melihat dari kesiapan calon mempelai laki-laki dan calon mempelai perempuan untuk menjalani rumah tangga.

Dilihat dari mașlahahnya, penetapan Hakim No. 266/P.dt.P/2020/PA.Pwr sudah sesuai mașlahah daruriyyah menjaga agama dan menjaga keturunan. Para Hakim Pengadilan Agama Purworejo telah mempertimbangkan supaya Para Pihak segera menjadi suami istri karena hubungan mereka yang sangat erat dan sudah dalam waktu yang lama akan sangat dikhawatirkan terjadi hal yang tidak diinginkan. Serta menolak kerusakan adanya pencemaran nama baik keluarga kedua belah pihak apabila terjadi hal tersebut.

REFERENCES (Book Antiqua 11,5 pt, Bold, Uppercase)

Abdurrahman. 2015. Kompilasi Hukum Islam. Jakarta : Akademika Pressindo

Candra, Mardi . 2018. Aspek Perlindungan Anak Indonesia. Jakarta: Kencana

Dahlan, Abd. Rahman. 2011. Ushul Fiqh. Jakarta: AMZAH

Departemen Agama RI. 2014. al-Qur'an dan Terjemahnya. Jakarta: Sygma

Departemen Pendidikan Nasional. 2011. Kamus Besar Bahasa Indonesia. Jakarta: Gramedia Pustaka Utama

Efendi, Satria. 2005. Ushul Fiqih, Jakarta: Prenada Media

Hadikusuma, Hilman. 2007. Hukum Perkawinan. Bandung: Mandar Maju

Haroen, Nasrun. 1996. Ushul Fiqih. Jakarta: Logo Publising House

HR, M. Hamim. 2017. Terjemah Fathul Qorib. Kediri: Santri Salaf Press

Mardaris. 2018. Metode Penelitian (Suatu Pendekatan Proposal) Cet. 10, Jakarta: Bumi Angkasa

Munawir, A. Warson . 1997. Kamus Al-Munawir. Surabaya: Pustaka Progresif

Suyatno. 2011. Dasar-Dasar Ushul Fiqh Dan Ushul Fiqh, Cet 1, (Yogyakarta: Ar-Ruzz Media

Syarifudin, Amir. 2008. Ushul Fiqih (2). Jakarta: Prenada Media Group . 2014. Ushul Fiqh Jilid 2. Jakarta: Kencana

Team Citra Umbara. 2017. Kompilasi Hukum Islam, (Bandung: Citra Umbara

Zuhri, Saifudin. 2011. Ushul Fiqih, (Yogyakarta: Pustaka Pelajar

Undang-Undang:

Pasal 7 Ayat (2) Undang- Undang No. 16 Tahun 2019.

Undang-Undang No. 1 Tahun 1974

Undang-Undang No. 16 Tahun 2019.

Jurnal:

Muksana Pasaribu. 2014. Maslahat Dan Perkembangannya Sebagai Dasar Penetapan Hukum Islam, Jurnal Justitia No 4 
Musyarrafa, Nur Ihdatul . 2020. Batas Usia Pernikahan Dalam Islam. Jurnal Shautuna, Vol. 1, No. 3, September 2020.

Nilda Susilawati. 2015. Statifikasi Al-Maqasid Al-Khamsah Dan Penerapannya Dalam Ad-Dharuriyat, Al-Hajiyyat, At-Tahsiniyyat, MIZANI, Vol. IX, No. 1,

Safrin Salam. 2017. Dispensasi Pernikahan Anak Di Bawah Umur Dalam Presfektif Hukum Adat, Hukum Negara Dan Hukum Islam, Jurnal Pagaruyuang, Vol. 1 No. 1

\section{Dokumen:}

Penetapan No. 266/Pdt.P/2020/PA.Pwr

Data dari Dokumen Pengadilan Agama Purworejo 